\title{
Optimization Model for the Implementation of Rock Mining Policy Post Law Enactment of the Republic of Indonesia Number 23 the Year 2014: Case Study in Subang Regency, West Java Province
}

\author{
Gede Suyasa ${ }^{1}$, Muchlis Hamdi ${ }^{2}$, Prio Teguh ${ }^{3}$, Megandaru ${ }^{4}$ \\ 1234 Program Doktoral Pascasarjana Institut Pemerintahan Dalam Negeri (IPDN), Indonesia \\ Email: suyasa76_2001@yahoo.co.id
}

\begin{abstract}
The purpose of this study was to find a model for optimizing rock mining licensing in the Subang Regency area after the enactment of the law of the Republic of Indonesia number 23 of 2014. The method used in this study was a qualitative method by interviewing relevant parties and searching literature. The results showed that the implementation of the policy on the issuance of rock mining permits in the Subang regency region after the enactment of the Law of the Republic of Indonesia Number 23 of 2014 was not running optimally, it was influenced by several factors such as the presence of actors consisting of Bureaucracy, Entrepreneurs and Communities having different interests but mutually related to one another in the process of issuing a rock mining permit after the authority to manage the rock mine was carried out by the province of West Java. The optimization model for the issuance of rock mining permits in the Subang Regency of West Java Province can be applied by focusing on the aspects of good and dynamic processes with the principles of governance of the environmental environment on the elements of actors, interests \& relations.
\end{abstract}

Keywords: policy implementation; licensing; rock quarry; Indonesia.

\section{A. INTRODUCTION}

The enactment of the Law of the Republic of Indonesia Number 23 of 2014 has changed the paradigm of the management of Mineral and Coal Resources into decentralization at the provincial level. This raises problems because the Minerva Law was made based on Law Number 32 of 2004 which has a decentralized paradigm at the district/city level. Resulting in out of sync between the two regulations. But in its implementation, the provincial government is given the authority to issue mining business licenses if the government wants to optimize the decentralization of the authority of the provincial government as stipulated in Law Number 23 of 2014 (Isnaeni, 2018). This disharmony condition creates legal uncertainty for mining entrepreneurs so that it will affect the climate of the people's mining business (Firmansyah, 2015).

With the transfer of authority of the regency/city government to the Province in terms of mining activities, the mining licensing procedure is not simple, this will have implications for the process of obtaining permits which is getting longer and longer 
while the need for rock commodities in the region cannot be delayed because mining types rock is a mining commodity that is felt directly by the local community or mining producing area that is used in construction, both in the form of houses, roads and buildings (Akhmaddhian, 2017).

In the Presidential Regulation of the Republic of Indonesia, Number 58 of 2017 mentioned several projects carried out in the area of West Java Province, namely a. toll road infrastructure development projects; $b$. The infrastructure development project for inter-city railroad facilities and infrastructure consists of Double Track South Java, Jakarta-Bandung High-Speed Train; c. the new airport construction project, Kertajati Airport; d. new port development project capacity building funds; e. Oil Refinery Development Program for upgrading existing refineries (RDMP); f. Waste Origin Energy Infrastructure Project; g. Drinking water supply project; h. The Dam and Irrigation Network Project consists of Kuningan Dam, Ciawi, Sukamahi, Leuwikeris, Cipanas, Bener, Sadawarna, Matenggeng, the construction of the Leuwigoong Irrigation Area Irrigation Network in Garut Regency.

From 27 (twenty-seven) districts/cities in West Java province, according to data from the Department of Energy and Mineral Resources of West Java Province in 2018, only 17 districts/cities have a mined source with a total number of IUPs issued around 390 and of the total about 342 IUP types rocks or around $87 \%$ of rock mines are in the province of West Java, one of the districts that have a source of rock mining is the Subang district (ESDM Department of West Java Province, 2018).

Subang Regency has a strategic location in West Java Province related to national project infrastructure development. Subang Regency is crossed by the northern coastline which is one of the busiest in Java. Subdistrict cities that are on this path include Ciasem and Pamanukan. Besides being crossed by the Pantura line, Subang Regency is also crossed by the Alternative Roadway of Sadang Cikamurang, which crosses in the middle of the Subang Regency area and connects Sadang, Purwakarta Regency with Tomo, Sumedang Regency. Subang Regency which is directly adjacent to Bandung Regency in the south has direct access which also connects the northern coastline with the city of Bandung (BPS Subang Regency, 2018).

With the strategic location of the Subang Regency related to the development of national strategic projects, it will increase the rock mining activities in the area. As published in the Buana Indonesia.co.id online news, it is stated that there are allegedly 8 illegal C excavations contributing to environmental destruction in Subang Regency. Some of the mines were closed down in 2014, but lately, these illegal mines have resumed operations. Some of the environmental destruction activities carried out by mining or C excavation in Subang Regency include red earth excavation in Rancabango village, Cikaum red earth excavation, red earth excavation in Kalijati, excavation in the Ranggawulung forest area, red earth excavation in Cicadas Binong, earth excavation red in West Pagaden, Sand excavations in Cipeundeuy and Galian Batu in the village of Ci- 
manglid Kasomalang (Ripai, 2018).

The purpose of this research is to analyze the effectiveness of the implementation of policies related to the abolition of district/city government authority in rock mining activities after the enactment of Republic of Indonesia Law number 23 of 2014 in the Subang Regency, West Java Province. This research is important because it has its own advantages with other researches, in which in this study the focus discusses the implementation of rock mining policies that have a direct effect on the interests and welfare of the communities around the mine and this research data is relatively new because this research focuses on post-mining rock permits. Law number 23 of 2014.

\section{B. METHOD}

The study uses descriptive analysis design with a qualitative approach (Creswell, 1994). In accordance with the research method and approach used, the data collection process carried out in scientific conditions (natural setting) refers to participatory observation, in-depth interviews, and documentation. According to Marshall and Rossman "the fundamental methods are relied on by qualitative researchers for gathering information are participation in the setting, direct observation, in-depth interviewing, document review" (Sugiyono, 2005).

Research informants were divided into three categories, namely mine owners, communities around the mine and policy implementers consisting of the One-Stop Integrated Investment Investment Office (DPMPTSP) of West Java Province, West Java Province ESDM Office, Subang Regency Environmental Agency, Subang Regency Revenue Service and Subang District Head village around the mine. Examination of data in qualitative research is very much needed data that is collected, trusted and shows the validity of solid data as the most strategic step in a study, because the main purpose of the validity check is getting data that meets the established standards. For this reason, the study uses representative patterns of data sources and data classification. Data validity, data classification, and data analysis are performed using a triangulation approach.

\section{RESULT AND DISCUSSION}

The model of policy implementation according to Grindle (1980) with two big variables, namely the contents of the policy and the implementation environment which are then broken down into 9 sub-variables, namely:

\section{Interest Affected}

To analyze this element the researcher asked the informant, what interests were affected by the policy of removing the authority of the Regency government in granting mining permits in accordance with Law No. 23 of 2014 in the Subang Regency? on the question, informants 1 and 2 (the ESDM office and DPMPTSP West Java Province) gave the answer: The affected interest is the interests of the Regency because with the enact- 
ment of law 23 of 2014 the authority of the district in issuing mining licenses is lost and from the original applicant feel shocked because there are habits that have changed greatly, where in the past when submitting an application in the Regency felt easier, faster because there were stages that could be bypassed such as in the exploration activity stage it might be possible to bypass only making an exploration report but with the transfer of authority in the Province these stages were enforced so tightly that they felt that issuing permits in the province was longer and more difficult.

On that question after being confirmed with informant 6 (mine owner) states: if the district that issued the permit is faster if there is money it must be worked out, for example, there is 100 million in cash, 200 million must be ready immediately, but if in the Province the process is longer and longer out of money also more, so just lie. In this case, Grindle (1980) argues that: "Differences in the level of behavior-changing programs for the beneficiaries are another way the contents of the policy affect its implementation".

Then Frumence (2013) said that: Decentralization is a system consisting of the transfer of power, authority, and functions from the center to local government, which has been recognized globally as a means to increase the delivery of public goods and services. The main objectives of the reform are to increase equity, increase efficiency and ensure more participation and responsiveness of the government to citizens.

Based on the results of interviews, secondary data and theory, the researchers are of the opinion that the parties whose interests are most affected are the mining workers' community (mining entrepreneurs), the Regional Revenue Service of Subang Regency and the West Java Provincial Energy and Mineral Resources Office as the technical service in the process of issuing permits for rock mining.

2. Type of Benefits

The researcher asked the informants, What types of benefits are expected by the government of West Java Province from the abolition of the authority of the Regency Government in granting rock type mining permits in accordance with Law Number 23 of 2014? and on this question informants 1 and 2 (the ESDM office and West Java Province DPMPTSP) gave answers that were expected one of which was good mining management, making none of the levels of government have absolute authority so between levels of government there could be mutual control so as not to If there is a conflict, then something like this must be a joint responsibility and between levels of government must be more harmonious.

Then Informant 6 (mine owner) gave an answer: although mining activities are carried out without permission there is no excessive conflict in the community, usually at most during the dry season there is a lot of dust, so if people are impatient the request is watered hastily, so if it's like so it can be up to 3 times to 4 times a day watering the road, in general the community supports the mining activities because the community there before there was sand most farmers if now many are open brick printing 
companies until now if I'm not mistaken there are about 25 brick printing companies, then motorcycle taxi drivers also able to buy Maxine cars for sand transport work.

Then informant 5 (the local village head) gave an answer: So far there has been no meaningful complaint because everything has been handled by the company, for example related to road damage has been repaired and even re-cast by the company, then related to dust caused by material carrier vehicles, the company has done watering up to 3 times a day and giving cashew money to residents of the house on the side of the road that is passed by a sand transport car.

Then informant 7 (the community around the mine) said: "There are no complaints, because there are many services for the company to the community, such as work, if there is a need, they also like to come here, for example, need sand, there are usually residents who ask for money on the road, then also There is money from the company, for houses that are on the side of the road, all left and right ".

In this case, Grindle said that: The difference in the level of behavior-changing the program for the beneficiaries is another way the contents of the policy affect its implementation. In addition, programs designed to achieve long-term goals may be more difficult to implement for those who are more concerned with immediate benefits. In this context, the contents of the policy become important to examine the direction of policy implementation.

Furthermore, Prasojo (2006) states that basically decentralization is classified into four types namely Deconcentration, Devolution, Delegation and Assistance Task. This co-administration task is also applied in Indonesia wherein the macro-agency task it is in the hands of the central government, funding sources are also from the center, while the micro policy and its implementation are carried out by the regional government. Therefore, determining the decentralized model must pay attention to its effectiveness, function, and usefulness (Muhammad, 2016).

From the answers of the informants and related to the opinions of Grindle and Prasosjo, et al, the researchers are of the opinion that the types and benefits expected from the provincial government will not affect the rock mining activities in the Subang area because the community only hopes how mining entrepreneurs pay attention to the surrounding environment and can help welfare community around the mine. If the expectation has been fulfilled by a rock mining entrepreneur, there will be no conflict caused by rock mining activities between the mining company and the community around the mine.

\section{The extent of Change Envisioned}

The researcher asked the question, what changes are desired through the abolition of the authority of the Regency Government in granting rock type mining permits in accordance with Law Number 23 of 2014? And on that question, Informant 1 and 2 (the ESDM office and DPMPTSP of West Java Province) gave an answer: "There is a change in the mining area map from a manual system to a digital system and increase 
regional income both in terms of land use and user fees for mining activities."

Then informant 6 (mine owner) gave an answer: When doing field scheduling, the consultant said we had to prepare the money first, then they came to the field and for WIUP I had to prepare 20 million of my own coincidences who handed in the space and then my own WIUP map printed it with costs incurred in the amount of Rp. 750,000 .

Then informant 4 (the Subang Regency Regional Revenue Service) gave an answer: Regarding mining management it is the province's authority but the tax on NonMetallic Minerals and Rocks (MBLB) is still received by the regency but related to mining tax collection issues we can only collect mining activities for which there are permits, the problem now is that in many areas mining activities do not have permits, we have also sent a letter to the Provincial Energy and Mineral Resources Office regarding the problem of mining activities in the Subang district.

In this case, Grindle (1980) states: The type of policy made will have a large impact on the type of political activity that is stimulated by the policymaking process. This observation can be applied with the same validity as the implementation process, encouraging consideration of the "capabilities" of various programs. Differences can also be made between programs that provide collective benefits, which encourage categorical making demands, and they provide shared benefits, which can mobilize more specific types of demands at the implementation stage.

From the answers of the informants and Grindle's view, the researcher is of the opinion that the changes expected by the transfer of authority have not been achieved optimally because the implementor still expects the rewards of providing services to the community as applicants for mining permits.

\section{Site of Decision Making}

The researcher asked the question, Who has the authority to make strategic decisions in determining the policy for granting mining permits for rock types after Law Number 23 of 2014 in West Java Province ?, for those questions, informants 1 and 2 (officials of the ESDM and DPMPTSP Province Offices) gave the answer: "The one authorized to make the strategic decision is the Governor or Regional Secretary through a proposal from the Head of Service at the Provincial level while the Regent at the Regency level".

Then the researchers asked additional questions who were the leading sector in granting the mining permit? To this question informant 2 (the PTPMDPM) gave the answer: Until now the institution that became the leading sector in granting mining permits in Subang Regency and in West Java Province was the Department of Energy and Mineral Resources of West Java Province and the leading sector should have been in the DPMPTSP, so we still depend on the technical service from the ESDM.

In article 19 of the Regional Regulation of West Java Province Number 2 of 2017 concerning the management of mineral and coal mining states "IUP issuance is carried 
out by regional authorities in charge of licensing matters", then in West Java Governor Regulation No. 62 of 2016 concerning the main tasks, functions, details of unit tasks and the work of DPMPTSP article 17 (1) states that the forestry, environment, energy and mineral resources section has the main task of carrying out forestry sector licensing, the environment, energy, and natural resources, including licensing registration processes, technical considerations, and processes licensing issuance. For this reason, the researchers are of the opinion that there is still overlapping of authority at the provincial level so that a willingness or policy from the Governor / Secretary of the region is required to combine the technical services related to licensing in one office with DPMPTSP, so that DPMPTSP can become a leading sector in granting permits mining.

\section{Implementation Program}

The researcher asks the question, how is the law implemented and who is implementing the law? then informants 1 and 2 (from the ESDM Office and DPM PTSP Jabar) gave an answer: The one implementing the law or regulation is the West Java Province DPMPTSP as a place for licensing registration and issuing licenses, where registration is done online, the ESDM Office in West Java Province discussion of the technical aspects and then the results of the technical study were submitted to DPM PTSP.

Then informant 2 (PTPM DPM) continued the answer: Related to licensing issues, technical agencies are still not optimal because the main tasks of technical agencies are more in the field of mining management supervision so that in terms of licensing it cannot be carried out optimally and the most common obstacle is HR. where the technical team has not been attached to us, so when we do the schedule to check the field we often find it difficult to equalize the schedule because the technical team is still ad hoc, when we submit to check the field related to technology licensing they have other duties from the leadership, usually they always argue like that so ask for the schedule to be postponed to find the right schedule.

In this perspective, Grindle (1980) said: Decisions made during policy formulation can also indicate who will be charged with implementing various programs, and those decisions can influence how policies are achieved. There may be, for example, differences in bureaucratic institutional capacity to manage program successes. Some receive greater support from the political elite and have access to resources, and some will be better able to handle the demands made on them.

Based on the information and opinion of the Grindle, the researchers are of the opinion that the executor of the rock mining permit issuance program should be the PTSP DPM assisted by a technical team from the ESDM Department of West Java Province, but the program implementers are still not optimal in conducting their activities according to their respective tasks and duties so as to hamper the provision licensing in the district of Subang. 


\section{Resources Committee}

The researcher asks the question, what resources are needed to support the effectiveness of granting mining permits for rock types after Law Number 23 of 2014 in the Subang Regency and how are these resources available within the Provincial Government as implementing the policy? then informant 2 (PTPMDPM) gave the answer: The required resources are human resources, related to the number of personnel and technical quality of the personnel, Budget, related to increasing allowances for human resources who carry out tasks in the mining and licensing fields, Technology, integrated technology from the PTSP service is needed with related technical offices, so that everything can be done online and from these resources it is explained that the performance of resources has not been maximized, because there are still many employees who do not have technical qualifications and employees from District governments that still have the old mindset are empowered in their old locations, so that there are still many opportunities to play outside the SOP, while operational budget resources have no constraints because what we need local governments to always respond to and related to integrated technology ri still found obstacles in accordance with the answers given and in the process of issuing permits should change the status of the PTSP Coordinating Board to the PTSP Investment Office, PTPM DPM must have become the leading sector in granting permits but the leading sector is still in the ESDM Office.

Then informant 1 (ESDM Department of West Java Province) added: "Human resources must be sufficient both in terms of quantity and quality, so far the Energy and Mineral Resources Agency is lacking in control of Mining".

In this case, Grindle (1980) said: Decisions made during policy formulation can also indicate who will be charged with implementing various programs, and those decisions can influence how policies are achieved. There may be, for example, differences in bureaucratic institutional capacity to manage program successes. Some receive greater support from the political elite and have access to resources, and some will be better able to handle the demands made on them.

Based on the answers from the informants and Grindle's opinion, the researchers are of the opinion that the government has not yet provided optimal human resources so that this lack of human resources is one of the obstacles in providing services to the public regarding mining licensing.

\section{Involved Power, Interests, and Strategies of Actors}

The researcher asked the question, who was involved in granting mining permits after the enactment of Law Number 23 of 2014 concerning the Regional Government? Then informants 1 and 2 gave answers: Who was involved in granting mining permits after the enactment of Law Number 23 of 2014 concerning The Regional Governments, among others, are from the Province: the PTSP Capital Investment Service as the issuer of permits and the ESDM Service as a technical party, and the Subang District Office of the Environment and Regional Revenue Service. 
Then proceed with the question, what interests are affected by the policy of removing the authority of the Regency government in granting mining permits in accordance with Law Number 23 of 2014 in the Subang Regency area? Based on this question, informants 1 and 2 (the ESDM and DPMPTSP West Java Province) gave answers: The affected interests were: from the Regency because with the enactment of Law 23 the abolition of the Subang district authority related to mining permit issues, then from the applicant, initially felt shock because there are habits that have changed greatly, where in the past when submitting an application in the Regency felt easier, faster because there were stages that could be skipped such as in the exploration activity stage it could possibly be skipped by only making an exploration report but by moving authority in the Province the stages are enforced so tightly that they feel that issuing permits in the province is longer and more difficult.

Then proceed with the question, are there problems that arise from the interests that are affected, and how to overcome these problems? informant 1 (ESDM Office of West Java Province) gave an answer: there is still the connotation of this permit which is a wet part so almost all regencies in Indonesia basically do not sincerely turn to the Province there are many whose livelihoods are lost but regionally systematic and comprehensive arrangements should be better. The purpose of "the wet part" is that there is an interest in the Regency government economically for personal gain from the regional head or a person in the Regency.

Then proceed with the question, How does the Government of West Java Province overcome the problems posed? then informants 1 and 2 (Department of Energy and Mineral Resources and DPMPTSP of West Java Province) gave an answer: By creating an online system for mining permit issuance where contact between the applicant and the licensing manager has diminished, only the problem is that licensing processes such as mining and our environment are known The term Subjective Documents where this document is only true according to what makes it needs to be tested is where it is impossible to avoid contact because related documents must be discussed so inevitably we have to meet, this is an online obstacle so not everything can be done online.

Then informant 3 (the Subang District Environmental Management Agency) gave an answer: One of the influences was the change in the form of the organization which was in the form of the Regency Environment Agency or Agency, now has become the Office and joined the Sanitation Sector and now that issues the environmental permit through DPMPTSP Regency Subang was previously issued directly by the Subang District BLH, whereas in terms of performance related to mining licensing is still the same and we are even more pleased that the authority was transferred to the Province because we in providing recommendations have a long time to look at the situation on the ground.

And informant 4 (the Subang Regional Revenue Service) gave an answer: if we can collect taxes do not deal with permits such as withdrawals on land and building 
taxes, essentially they have objects that we can withdraw from the UN, as well as in mining activities if they carry out activities we can Withdraw the tax, while informant 6 (the mining worker) gives an answer "usually the game is still in the process of environmental permits and technical discussions in the branch offices, if I see it that way but if in the DPMPTSP I think there is no the game because they only accept finished goods from the technical service.

Informant 6 (the mine owner) gave an answer: if for example taking care of it doesn't beat around the clock faster and the tax will come in faster, if it's like this then we want to pay taxes, how can we pay taxes too, we finally coordinate with the local authorities and mine area environment.

Grindle (1980) said: We have compiled the implementation into a decision making process that will involve various actors. In the administration process of each given program, many actors are called to make choices about the allocation of specific public resources and many other things may be tried to influence decisions. A shortlist of people who might be involved in implementing a program will include national-level planners, national, regional and local politicians, economic elite groups, especially at the local level, recipient groups, and bureaucratic implementers at the middle and lower levels. These actors are more or less involved in implementation, depending on the contents of the program and the form given. Each may have a special interest in the program, and each may strive to achieve this by making demands on the allocation procedure.

Based on the information from the informants and Grindle's opinion, the researcher is of the opinion that there is still a conflict of interest between the DPM PTSP as the issuer of permits and the ESDM service as a technical function that provides technical recommendations for mining permits, and for that interest DPM PTSP hopes that the issuance of one-stop licenses is truly implemented by combining technical services in one building with DPMPTSP so that synergy occurs in the provision of mining licensing services to the region.

\section{Institution and Regime}

The researcher asked the question, How is the support of the relevant agencies in implementing the policy of granting mining permits for rock types after Law Number 23 of 2014 in the Subang Regency ?, then informant 2 (DPMPTSP) gave an answer: in Subang Regency and in West Java Province is the ESDM Office of West Java Province and the leading sector should be in the DPMPTSP, so we are still dependent on the ESDM technical department and related to licensing issues, the technical agencies are still not optimal because the main technical agencies are more supervisory mining management, so that in terms of licensing can not be implemented optimally.

Then informant 6 (the mine owner) gave an answer: usually, the game was when handling environmental permits and technical discussions at the branch office if I look at it that way but if at DPMPTSP I think there is no game because they only accept ma- 
ture goods from the technical service.

In this case, Grindle (1980), said: What is implemented may be the result of the calculation of political interests and competing groups for scarce resources, responses from implementing officials, and actions of political elites, all interacting in the given institutional context. An analysis of the implementation of specific programs can be interpreted to assess the "ability" of actors, their interests and strategies to achieve them, and the characteristics of the regimes in which they interact. This, in turn, can make it easier to assess the potential for achieving policy and program objectives.

Based on the informant's answer, the researcher is of the opinion that the institutional characteristics and regimes associated with the granting of permits for rock mining with the transfer of authority have not changed so that there are still characteristics to be served and expect compensation from the public in providing licensing services.

\section{Compliance and Responsiveness}

The researcher asked the question, is there any rejection from both the community and the local government of the Subang Regency related to the abolition of the authority of the Subang Regency government regarding the granting of a type of rock mining permit after Law Number 23 of 2014 in the Subang Regency area? then informants 1 and 2 (from DPMPTSP and the ESDM Office of West Java) gave an answer: Initially there were many rejections made either by the Regency / City Government or companies or communities that applied for permits, the initial problem of the Regency / City was because they felt their authority eliminated while on the part of the applicant because the licensing process is getting longer and longer and the policies being made more stringent.

Then informant 5 (the village head whose area has rock mining activities) said: We expect the licensing process to be expedited sooner and the process should not be too complicated because once again from the community there are no problems related to mining activities and here there are community needs as well as related village government needs development problem.

And informant 6 (the mine owner) gave a statement: if the district that issued the permit was faster, if there was money, it would have been worked out, for example, there was 100 million, 200 million would have been immediately made, but if in the Province the process was long and the money was out longer. a lot, that's why it's a lie.

Grindle (1980) says that: The other side of the policy problem and achieving program goals in a particular environment is responsiveness. Ideally, public institutions such as bureaucracy must be responsive to the needs that are most adequate for them to serve them. In addition, without sufficient responsiveness during implementation, public officials who lose information to evaluate program achievements to be effective, then, implementers must be skilled in the art of politics and must understand well the environment in which they strive to realize public policies and programs ". Then related to compliance Grindle stated "In achieving a goal officials face two problems that high- 
light the interaction of the program environment and program administration. First, officials must address the problem of how to achieve policy compliance. They must, for example, obtain support from the political elite, and compliance with implementing agencies, the imposition of bureaucracy by implementing programs from lower-level political elites, and beneficiaries.

Permission data obtained from DPMPTSP West Java in 2019, found information that from 2015 to 2018 the number of mining permit applicants from the Subang district was 65 requests and from the number of applicants it had only been completed as many as 12 licenses, the duration of WIUP issuance ranging from 4 months up to 18 months. Whereas in the attachment of the Minister of Energy and Mineral Resources Regulation No. 43 of 2015 the period of issuance of WIUP issuance is 14 days, the Exploration IUP of 14 days and the IUP of OP for 14 days and the Governor of West Java No. 1 of 2018 concerning the regulations on implementing the implementation of a one-stop integrated service WIUP for 60 days, 30-day Exploration IUP and 60-day OP IUP.

Based on the information from the informants and Grindle's opinion, the researcher is of the opinion that the consistency and responsiveness of the provincial government to the mining permit issuance process after law no. 23 of 2014 is not optimal so that the issuance of rock mining permits in the Subang district area can never be completed in a timely manner. already determined.

\section{CONCLUSION}

The implementation of the policy on the issuance of rock mining permits in the Subang district area after the enactment of the Law of the Republic of Indonesia Number 23 of 2014 has not run optimally, it is influenced by several factors, namely: the presence of actors consisting of bureaucracy, entrepreneurs and the public have different interests but are interrelated another in the process of issuing a rock mining permit after the authority to manage a rock mine was carried out by the province of West Java. The optimization model for the issuance of rock mining permits in the Subang Regency, West Java Province can be applied by focusing on the aspects of a good and dynamic process with the principles of governance of the environment on the elements of actors, interests, and relations. 


\section{REFERENCES}

1. Adhayanto, O., \& Adiputra, Y. S. (2015). Dampak Undang-Undang Nomor 23 Tahun 2014 Terhadap Peraturan Daerah di Kabupaten Bintan Tahun 2015 (Studi Peralihan Kewenangan Dibidang Kelautan dan Pertambangan). Jurnal Selat, 2(2), 296-314.

2. Akbal, M. (2017). Harmonisasi Kewenangan Antara Pemerintah Pusat Dan Daerah Dalam Penyelenggaraan Otonomi Daerah. Jurnal Supremasi, 11(2), 100-110.

3. Bennett, N. J., \& Satterfield, T. (2018). Environmental governance: A practical framework to guide design, evaluation, and analysis. Conservation Letters, 11(6), e12600.

4. Cheema, G. S., \& Rondinelli, D. A. (Eds.). (2007). Decentralizing governance: emerging concepts and practices. Brookings Institution Press.

5. Central Statistics Agency. (2018). Subang Dalam Angka. Subang: BPS Kabupaten Subang.

6. Conyers, D. (1986). Decentralisation and development: a framework for analysis. Community Development Journal, 21(2), 88-100.

7. Creswell, J. W. (1994). Reaserch Design, Pendekatan Metode Kualitatif, Kuantitatif dan Campuran. Jakarta: Pustaka Pelajar.

8. Department of Energy and Mineral Resources of West Java Province. (2018). Data Perizinan tambang Provinsi Jawa Barat. Bandung: Dinas ESDM Provinsi Jawa Barat.

9. Firmansyah, A. A., \& Evendia, M. (2015). Harmonisasi Pengaturan Kewenangan Daerah Bidang Pengelolaan Pertambangan Mineral Bukan Logam dan Batuan. Kanun: Jurnal Ilmu Hukum, 17(1), 19-36.

10. Frumence, G., Nyamhanga, T., Mwangu, M., \& Hurtig, A. K. (2013). Challenges to the implementation of health sector decentralization in Tanzania: experiences from Kongwa district council. Global health action, 6(1), 20983.

11. Government Regulation Number 23 of 2010 concerning implementation of Minerba Mining activities.

12. Grindle, M. S. (1980). Politics and Policy Implementation in The Trird World. New Jersey: Priceton University Press.

13. Hilmawan, R., Yudaruddin, R., \& Wahyuni, Y. S. (2016). Coal Mining Operations and Its Impact on Sectoral and Regional Area: Evidence of East Kalimantan, Indonesia. Journal of Indonesian Applied Economics, 6(1), 22-43.

14. Isnaeni, D. (2018). Implikasi Yuridis Kewenangan Pemerintah Daerah Dalam Pemberian Ijin Usaha Pertambangan Menurut Undang-Undang Nomor 23 Tahun 2014. Yurispruden: Jurnal Fakultas Hukum Universitas Islam Malang, 1(1), 35-46.

15. Kaho, J. R. (1988). Prospek Otonomi Daerah di Negara Republik Indonesia. Jakarta: Rajawali Pers.

16. Kaloh, J. (2007). Mencari bentuk otonomi daerah: suatu solusi dalam menjawab kebutuhan 
lokal dan tantangan global. Jakarta: Rineka Cipta.

17. Law Number 23 of 2014 concerning Regional Government.

18. Law Number 4 of 2009 concerning Minerba.

19. Local regulation number 1 of 2014 concerning non-metal mineral and rock mining businesses.

20. Mandala, E., Setyadiharja, R., Jefri, J., Renaldi, R., \& Mulyani, N. (2016). Implementasi Kebijakan Penerbitan Surat Persetujuan Berlayar (SPB). Jurnal Ilmu Pemerintahan: Kajian Ilmu Pemerintahan dan Politik Daerah, 1(2), 249-269.

21. Mason., A. (1942). Public Policy. Harvard: The Graduate School of Public Administration.

22. Mina, R. (2016). Desentralisasi Perlindungan Dan Pengelolaan Lingkungan Hidup Sebagai Alternatif Menyelesaikan Permasalahan Lingkungan Hidup. Arena Hukum, 9(2), 149-165.

23. Muluk, K. (2006). Desentralisasi Pemerintahan Daerah. Jakarta: Bayumedia.

24. Prasojo, E. (2006). Reformasi Birokrasi di Indonesia: Beberapa Catatan Kritis. Jurnal Ilmu Administrasi dan Organisasi, Bisnis E Birokrasi, 14(1).

25. Presidential Regulation Number 58 of 2017 concerning Amendment to Presidential Regulation Number 3 of 2016 concerning the Acceleration of the Implementation of National Strategic Projects.

26. Regional Regulation number 7 of 2001 concerning mining operations.

27. Regional regulation number 6 of 2016 concerning the formation and arrangement of regional apparatus of West Java Province.

28. Regional Regulation number 2 of 2017 concerning the management of mineral and coal mining.

29. Ripley, R. (1986). Policy Implementation Bureaucracy. Cicago: Dorsey Press.

30. Risal, S. (2018). Pengelolaan Sumber Daya Alam di Era Desentralisasi. Jurnal Ilmiah Manajemen Publik dan Kebijakan Sosial, 1(2), 122-132.

31. Rumengan, J., Karamoy, H., \& Pusung, R. (2016). Efektivitas Pajak Pengambilan dan Pengolahan Bahan Galian Mineral Bukan Logam dan Batuan di Kabupaten Minahasa Selatan. Jurnal EMBA: Jurnal Riset Ekonomi, Manajemen, Bisnis dan Akuntansi, 3(4), 509-517.

32. Siong, N. B., \& Geraldine, C. (2007). Dynamic Governance: Embedding Culture, Capabilities And Change In Singapore (English Version). World Scientific.

33. Sugiyono. (2005). Metode Penelitian Kuantitatif Kualitatif dan RED. Bandung: Alfabeta.

34. Suhartono, S. (2013). Desentralisasi Pengelolaan Sumber Daya Alam Untuk Mewujudkan Kesejahteraan Masyarakat. DiH: Jurnal Ilmu Hukum, 9(18), 110-121.

35. Supriatin, L., \& Akhmaddhian, S. (2017). Kewenangan Perizinan Usaha Pertambangan Pasca Berlakunya Undang Undang Pemerintah Daerah (Studi di Kabupaten Kuningan Provinsi Jawa Barat). UNIFIKASI: Jurnal Ilmu Hukum, 4(2), 64-76.

36. West Java Governor Regulation No. 62 of 2016 concerning the main tasks, functions, 
details of the DPMPTSP unit's work and work duties.

37. Widayati, S., Usman, D. N., \& Sriyanti, S. (2014). Ekonomi Lokal Sebagai Bagian Dari Pengembangan Wilayah Pertambangan Yang Berdampak Terhadap Pendapatan Daerah (Studi Kasus Pertambangan Pasir dan Batuan Kab. Bandung Barat). Prosiding SNaPP: Sains, Teknologi, 4(1), 499-504. 